\title{
Environmentally Liable Multi-Objective Multi Time Span Fuzzy Fractional Capacitated Transportation Problem in the Two Echelon Supply Chain with Heterogeneous Items and Mixed Constraints
}

\author{
P. Vijayalakshmi, J. Merline Vinotha
}

\begin{abstract}
In today's world supply chain is an integral part of business. This paper proposed a model of environmentally liable multi-objective multi time span fuzzy fractional capacitated transportation problem (ELMOMTHIFFCTP) in the two echelon supply chain with heterogeneous items and mixed constraints. In this model, few objectives are considered as a linear function and few are fractional functions. Especially the objective function related to emission cost is considered as linear fractional objective function. The damage cost, labor cost, packing cost and quality cost are considered as triangular intuitionistic fuzzy numbers. This paper focuses on minimization of damage cost, labor cost, quality cost, packing cost and the ratio related to transportation cost, inventory carrying cost and emission cost of the entire supply chain. An industrial case demonstrates the feasibility of applying the proposed model to real world problem in a two echelon supply chain under uncertain environment also determine an optimal inventory level for the warehouse and distribution centers using fuzzy programming approach through LINGO software.
\end{abstract}

Keywords: Fuzzy programming approach, fractional capacitated transportation problem, heterogeneous items, multi -time span, two echelon supply chain.

\section{INTRODUCTION}

Transportation problem is a special case of linear programming problem which was first introduced by F. L. Hitchcock since 1941. The main objective of TP is to minimize the cost of transportation from sources to destinations so as to satisfy the supply and demand conditions.

In the crisp environment, all parameters related to transportation problem are known precisely to the decision maker, the parameters may take imprecise values due to fluctuation in the market and some other reasons, therefore, in such cases, the fuzzy number can be used to represent this imprecision in data. Bellman and Zadeh (1970) and Zadeh (1978) proposed the concept of fuzziness.

An intutionistic fuzzy set is extension of fuzzy set theory. It was first developed by Atanassov's (1986). An intutionistic fuzzy set deals with the membership functions and non

Revised Version Manuscript Received on July 10, 2019. TN, India.

P. Vijayalakshmi, Hindusthan Institute of Technology, Coimbatore, India member functions. Basic arithmetic operations of TIFN are defined by Deng-Feng Li in 2008. Basic arithmetic operations of TIFNs such as addition, subtraction and multiplication are defined by S.Mahapatra and T.K.Roy in (2009), by considering the six tuple number itself.

The classical TP deals with the transportation of single items with single objective. But in the present scenario single objective transportation problem is not fulfill the requirements. To overcome this situation Charnes and Cooper was introduced the concept of multi-objective transportation problem (MOTP) in the year 1961. Many researchers have studied the multi objective fuzzy transportation problem (MOFTP). Tanaka et al., Zimmerman, Buckley and Feuring, Thakre et al. and Zhang were discussed the several methods of finding optimal solution of MOFTP.

During the transportation of goods the capacity of the transport is not specified, there are many issues related to storage, total budget, safety of environment. To tackle this situation, Wagner (1959) has studied the capacitated TP. Traditional transportation problems are confined to a particular span. But in reality, the distribution decisions are prolonged for more than one time frame, because it provides a chance to take advantage in lot sizing. Hence the transportation of heterogeneous items in the multi time span has much practical significance.

Fractional objectives are more realistic because the ratio to be optimized often describes some kind of efficiency of a system. Fuzzy programming technique is more efficient and consistent with dealing fractional objectives to find compromise solution. Gupta N(2014) discussed the fuzzy multi objective capacitated transportation problem with mixed constraints. Several researchers have used fuzzy programming technique to solve MOCTP with fractional objectives( Srikant Gupta et.al 2018).

Transportation plays a most important role in distribution of goods from the producers to the customers. Supply chain is the combination of producers, distributors and retailers. The main aim of supply chain is to provide the sustainable competitive advantage. Several researchers have studied 


\section{ENVIRONMENTALLY LIABLE MULTI-OBJECTIVE MULTI TIME SPAN FUZZY FRACTIONAL CAPACITATED TRANSPORTATION PROBLEM IN THE TWO ECHELON SUPPLY CHAIN WITH HETEROGENEOUS ITEMS AND MIXED CONSTRAINTS}

supply chain (Beamon (1998), Anamaria and Rakesh (1999), Bilgen and Ozkarahan (2004), Gen and Syanf (2005), Stank and Goldsby (2000), Potter and Lalwani (2005), Disney and Jowill, 2003, Childhouse P., Jowill D.R. 2003, Bask A.H., 2001).

In the supply chain problems, during the production of food products the producers must aware of quality of foods. To overcome this situation, appraisal cost or inspection cost is introduced. The amount spend during the inspection of products is defined as appraisal cost. This cost creates some awareness about safety of foods.

In addition to that packaging cost is a powerful part in supply chain. Packaging is highly convenient user friendly safe and hygienic to store any products such as ghee, oil etc. The system of packaging that involves efficient distribution and consumption of goods and hence packaging is important to all transportation to assure safety shipment.

Global warming is the greatest threat to all human beings in the prevailing situation. Emission from transportation plays a vital role in environmental degradation. A general awareness should be created to all the users of transports so as to save the environment. So developing the model

According to the best of our knowledge none of the authors have discussed fractional objectives in supply chain under fuzzy environment. The objective of the proposed model is to minimize the damage cost, labor cost, quality cost, packing cost and the ratio related to transportation cost, inventory carrying cost and emission cost of the entire supply chain. Also this proposed model is applied for one of the leading ghee company as a case study to determine feasibility of the proposed model.

The rest of the paper is organized as follows. In section 2 the preliminary concepts related to TIFN are discussed. Description of the problem, assumptions and notations are given in section 3. Formulation of environmentally liable multi-objective, multi time span fuzzy fractional capacitated transportation problem in the two echelon supply chain with heterogeneous items and mixed constraints are presented in section 4. Solution methodology is discussed in section 5. Industrial case study for implementing the feasibility of applying the proposed approach to real situations is presented in section 6. Results and conclusion is discussed in section 7.

\section{PRELIMINARIES}

\section{Definition: 2.1 Intuitionistic fuzzy number}

$\begin{array}{lll}\text { An } & \text { intuitionistic } & \text { fuzzy }\end{array}$ called intuitionistic fuzzy number if

(i) There exit a real numbers $x_{0} \in R$ such that

$$
\mathrm{m}_{I F}\left(x_{0}\right)=1 \text {, and } \mathrm{n}_{I F}\left(x_{0}\right)=0 \text {, }
$$

(ii) Membership $\mathrm{m}_{A}$ of ${ }^{I F} A$ is fuzzy convex and non-membership $\mathrm{n}_{A}$ of $\mathrm{A}$ is fuzzy concave.

(iii) $\mathrm{m}_{I F}$ is upper semi -continuous and $\mathrm{n}_{I F}$ is lower semi-continuous. (iv) Support $\left({ }^{I F} A\right)=\overline{\left(\left\{x \in R: \mathrm{n}_{I F}(x)<1\right\}\right)}$ is

bounded.

Definition:2.2 Triangular intuitionistic fuzzy number is denoted by

$$
{ }^{I F} A=\left\{\left(c_{1}, c_{2}, c_{3}\right)\left(d_{1}, c_{2}, d_{3}\right)\right\} \text {, where } c_{1}, c_{2}, c_{3}, d_{1}, d_{3} \in R
$$

such that $d_{1} \leq c_{1} \leq c_{2} \leq c_{3} \leq d_{3}$ is an intuitionistic fuzzy numbers having membership and non-membership functions is of the form

$\mu_{I_{A}}(x)=\left\{\begin{array}{l}1, \\ 0, \\ j_{A^{\prime}}(x), \\ c_{A^{\prime}}(x),\end{array}\right.$

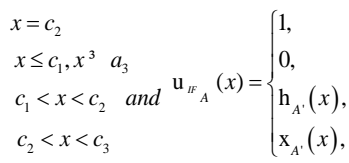

$$
\begin{aligned}
& x=c_{2} \\
& x \leq c_{1}, x^{3} \quad c_{3} \\
& d_{1}<x<d_{2} \\
& d_{2}<x<d_{3}
\end{aligned}
$$

Where $\mathrm{j}_{I F}$ :

$$
\left(c_{1}, c_{2}\right) \rightarrow[0,1], \mathrm{c}_{I F}:\left(c_{2}, c_{3}\right) \rightarrow[0,1], \mathrm{h}_{I F}:\left(d_{1}, c_{2}\right) \rightarrow[0,1], \mathrm{X}_{I F}:\left(d_{2}, d_{3}\right) \rightarrow[0,1] .
$$

Definition:2.3

(1) The addition of two triangular intuitionistic fuzzy number $\left.{ }^{I F} A_{1}=\left\{\mathrm{c}_{11}, \mathrm{c}_{21}, \mathrm{c}_{31}\right),\left(\mathrm{d}_{11}, \mathrm{c}_{21}, \mathrm{~d}_{31}\right)\right\}$ and ${ }^{I F} A_{2}=\{($ $\left.\left.\mathrm{c}_{12}, \mathrm{c}_{22}, \mathrm{c}_{32}\right),\left(\mathrm{d}_{12}, \mathrm{c}_{22}, \mathrm{~d}_{32}\right)\right\}$ is defined as

${ }^{I F} A_{1} \AA^{I F} A_{2}=\left\{\left(\mathrm{c}_{11}+\mathrm{c}_{12}, \mathrm{c}_{21}+\mathrm{c}_{22}, \mathrm{c}_{31}+\mathrm{c}_{32}\right)\left(\mathrm{d}_{11}+\mathrm{d}_{12}\right.\right.$, $\left.\left.\mathrm{c}_{21}+\mathrm{c}_{22}, \mathrm{~d}_{31}+\mathrm{d}_{31}\right)\right\}$

(2) The scalar multiplication of ${ }^{I F} A$ by real number k $>0$ is defined as

$$
k^{I F} A=\left\{\begin{array}{l}
\left\{\left(\mathrm{ka}_{1}, \mathrm{ka}_{2}, \mathrm{ka}_{3}\right),\left(\mathrm{kb}_{1}, \mathrm{ka}_{2}, \mathrm{~kb}_{3}\right)\right\}, k>0 \\
\left\{\left(\mathrm{ka}_{3}, \mathrm{ka}_{2}, \mathrm{ka}_{1}\right),\left(\mathrm{kb}_{3}, \mathrm{ka}_{2}, \mathrm{~kb}_{1}\right)\right\}, k<0
\end{array}\right.
$$

Definition: 2.3 Sign distance function :-

Let $a, b \in \square$ be two real numbers, the sign distance between $a, b$ is defined as $D(a, b)=a-b$ since $D(a, 0)=a, D$ $(b, 0)=b$.

Definition: 2.4 Sign distance of triangular intuitionistic fuzzy numbers

Let ${ }^{I F} A^{\prime}=\left\{\left(\mathrm{c}_{1}, \mathrm{c}_{2}, \mathrm{c}_{3}\right),\left(\mathrm{d}_{1}, \mathrm{c}_{2}, \mathrm{~d}_{3}\right)\right\}$ be triangular intuitionist fuzzy number. The sign distance of $\mathrm{A}$ can be calculated as $D^{s}\left({ }^{I F} A,{ }^{I F} O\right)=\frac{c_{1}+c_{2}+c_{3}+d_{1}+d_{3}}{8}$

Definition: 2.4 Ranking of TIFN:-

Let ${ }^{I F} A=\left\{\left(\mathrm{c}_{1}, \mathrm{c}_{2}, \mathrm{c}_{3}\right),\left(\mathrm{d}_{1}, \mathrm{c}_{2}, \mathrm{~d}_{3}\right)\right\}$ be triangular intuitionistic fuzzy number. The ranking of a TIFN is

$$
R\left({ }^{I F} A\right)=\left(\frac{c_{3}-c_{1}}{d_{3}-d_{1}}\right) D{ }^{s}\left({ }^{I F} A, \quad I F\right)
$$

\section{DESCRIPTION OF THE PROBLEM, ASSUMPTIONS AND NOTATIONS}

The suggested model ELMOMTHIFFCTP with mixed constraints has NW warehouses, ND distribution centers and $\mathrm{Nr}$ retailers with limited capacities. In this model, 
heterogeneous items are distributed from the distribution centers to retailers according to their demand for every time span and will be used as the quotation for distribution centers to transfer stocks from them to retailers in a particular time span. The aim of this approach is to minimize the damage cost, labor cost, quality, packing cost the ratio related to transportation cost, inventory carrying cost, and emission cost of the entire supply chain.

The following list of assumptions is the basics for this study's mathematical programming model.

1. Few objectives are fractional and other objectives are linear in nature.

2. The cost of transportation depends on the number of products.

3. Charge of packing is directly related to the product and type of the package material.

4. There is limited availability of the products in the warehouse and distribution centers. Following notations are used in this study.

Index set

$\mathrm{m}$ Ware houses

$\mathrm{m}=1,2, \ldots \mathrm{Nw}$

$\mathrm{n}$ Distribution centers

$\mathrm{n}=1,2 \ldots, \mathrm{ND}$

1 Retailers

$1=1,2 \ldots \mathrm{NR}$

$\mathrm{u}$ product type

$\mathrm{u}=1,2 \ldots \mathrm{Npr}$

v Time span

w stages

$\mathrm{u}=1,2, \ldots \mathrm{T}$

$\mathrm{v}=1,2$.

Objective function:

${ }^{I F} T C_{v 1}$ Total cost in the first stage. IF

$T C_{v 2}$ Total cost in the second stage.

$T C_{v}$ Total cost in span $\mathrm{v}$ is equal to sum of ${ }^{I F} T C_{v 1}$ and ${ }^{I F} T C_{v 2}$.

\section{Decision Valuables:}

$I W_{v u m} \rightarrow$ Level of inventory of $\mathrm{u}^{\text {th }}$ product in ELMOMTHIFFCTP by $\mathrm{m}^{\text {th }} \mathrm{WH}$ in time $\operatorname{span} v$.

$T W_{\text {vumn }} \rightarrow$ Units distributed of $\mathrm{u}^{\text {th }}$ product in ELMOMTHIFFCTP from $\mathrm{m}^{\text {th }} \mathrm{WH}$ to $\mathrm{n}^{\text {th }}$ DC in time span $\mathrm{v}$.

$I D_{v u n} \rightarrow$ Inventory level of $\mathrm{u}^{\text {th }}$ product in ELMOMTHIFFCTP in $\mathrm{j}^{\text {th }}$ DC in time $\operatorname{span} v$.

$T D_{\text {vunl }} \rightarrow$ Units distributed of $\mathrm{u}^{\text {th }}$ product in ELMOMTHIFFCTP from $j^{\text {th }}$ DC to $\mathrm{r}^{\text {th }} \mathrm{RT}$ in time span $\mathrm{v}$.

\section{Parameters:}

$I C W_{\text {vum }}{ }^{a} \rightarrow \quad$ Actual unit cost of carrying the inventory of $\mathrm{u}^{\text {th }}$ product in ELMOMTHIFFCTP by $\mathrm{m}^{\text {th }} \mathrm{WH}$ in time span v.

$I C W_{\text {vum }}{ }^{s} \rightarrow$ Standard unit cost of carrying the inventory $\mathrm{u}^{\text {th }}$ product in ELMOMTHIFFCTP by $\mathrm{m}^{\text {th }} \mathrm{WH}$ in time span $v$.
The following notations are used in this study.

$T C W_{\text {vumn }}^{a} \rightarrow$ Actual cost of transportation of $\mathrm{u}^{\text {th }}$ product in ELMOMTHIFFCTP from $\mathrm{m}^{\text {th }} \mathrm{WH}$ to $\mathrm{n}^{\text {th }} \mathrm{DC}$ in time span $\mathrm{v}$.

$T C W_{\text {vumn }}^{s} \rightarrow$ Standard unit transportation cost of $\mathrm{u}^{\text {th }}$ product in ELMOMTHIFFCTP from $\mathrm{m}^{\text {th }} \mathrm{WH}$ to $\mathrm{n}^{\text {th }}$ DC in time span $\mathrm{v}$.

${ }^{I F} Q_{\text {vumn }} \rightarrow$ Quality testing cost of $\mathrm{u}^{\text {th }}$ product in ELMOMTHIFFCTP from $\mathrm{m}^{\text {th }} \mathrm{WH}$ to $\mathrm{n}^{\text {th }}$ DC in time span $\mathrm{v}$.

$y_{\text {vumn }} \rightarrow$ Purity level of $\mathrm{u}^{\text {th }}$ product in ELMOMTHIFFCTP from $\mathrm{m}^{\text {th }} \mathrm{WH}$ to $\mathrm{n}^{\text {th }}$ DC in time span $\mathrm{v}$.

${ }^{I F} P C_{\text {vum }} \rightarrow$ Packing charge of $\mathrm{u}^{\text {th }}$ product in ELMOMTHIFFCTP by $\mathrm{m}^{\text {th }} \mathrm{WH}$ in time span $\mathrm{v}$.

${ }^{I F} d w_{\text {vumn }} \rightarrow$ Damage cost of $\mathrm{u}^{\text {th }}$ product in ELMOMTHIFFCTP from $\mathrm{m}^{\text {th }} \mathrm{WH}$ to $\mathrm{n}^{\text {th }}$ DC in time span $\mathrm{v}$.

$L W_{\text {vumn }} \rightarrow$ Labor cost of $\mathrm{u}^{\text {th }}$ product in ELMOMTHIFFCTP from $\mathrm{m}^{\text {th }} \mathrm{WH}$ to $\mathrm{n}^{\text {th }}$ DC in time span $\mathrm{v}$. $E C W_{\text {vumn }}^{a} \rightarrow$ Actual Emission cost of $\mathrm{u}^{\text {th }}$ product in ELMOMTHIFFCTP from $\mathrm{m}^{\text {th }} \mathrm{WH}$ to $\mathrm{n}^{\text {th }}$ DC in time span $\mathrm{v}$. $E C W_{\text {vumn }}^{s} \rightarrow$ Standard Emission cost of $\mathrm{u}^{\text {th }}$ product in ELMOMTHIFFCTP from $\mathrm{m}^{\text {th }} \mathrm{WH}$ to $\mathrm{n}^{\text {th }}$ DC in time span $\mathrm{v}$.

$I C D_{\text {vun }}^{a} \rightarrow$ Actual unit cost of carrying the inventory of $\mathrm{u}^{\text {th }}$ product in ELMOMTHIFFCTP by $\mathrm{n}^{\text {th }}$ DC in time span $\mathrm{v}$.

$I C D_{\text {vun }}^{s} \rightarrow$ Standard unit cost of carrying the inventory of $\mathrm{u}^{\text {th }}$ product in ELMOMTHIFFCTP by $\mathrm{n}^{\text {th }}$ DC in time span $\mathrm{v}$.

$T C D_{\text {vuml }}^{a} \rightarrow$ Actual cost of transportation of $\mathrm{u}^{\text {th }}$ product in ELMOMTHIFFCTP from $\mathrm{n}^{\text {th }} \mathrm{DC}$ to $\mathrm{l}^{\text {th }} \mathrm{RT}$ in time span $v$.

$T C D_{\text {vunl }}^{s} \rightarrow$ Standard cost of transportation of $\mathrm{u}^{\text {th }}$ product in ELMOMTHIFFCTP from $\mathrm{n}^{\text {th }}$ DC to $1^{\text {th }} \mathrm{RT}$ in time span $\mathrm{v}$.

${ }^{I F} d D_{\text {vunl }} \rightarrow$ Damage cost of $\mathrm{u}^{\text {th }}$ product in ELMOMTHIFFCTP from $\mathrm{n}^{\text {th }}$ DC to $1^{\text {th }}$ RT in time span $v$.

${ }^{I F} L D_{\text {vunl }} \rightarrow$ Labor cost of $\mathrm{u}^{\text {th }}$ product in ELMOMTHIFFCTP from $n^{\text {th }}$ DC to $1^{\text {th }}$ RT in time span v.

$E C D_{\text {vunl }}^{a} \rightarrow$ Actual Emission cost of $\mathrm{u}^{\text {th }}$ product in ELMOMTHIFFCTP from $\mathrm{n}^{\text {th }} \mathrm{DC}$ to $\mathrm{l}^{\text {th }} \mathrm{RT}$ in time span $v$.

$E C D_{\text {vunl }}^{s} \rightarrow$ Standard Emission cost of $\mathrm{u}^{\text {th }}$ product in ELMOMTHIFFCTP from $\mathrm{n}^{\text {th }} \mathrm{DC}$ to $\mathrm{l}^{\text {th }} \mathrm{RT}$ in time span $v$. IF

$F D_{\text {vun }} \rightarrow$ Forecasted demand of $\mathrm{u}^{\text {th }}$ product in ELMOMTHIFFCTP of $\mathrm{n}^{\text {th }}$ DC in time span $v$.

${ }^{\text {IF }} A D_{\text {vun }} \rightarrow$ Actual demand $\mathrm{u}^{\text {th }}$ product in ELMOMTHIFFCTP of $\mathrm{n}^{\text {th }}$ DC in time $\operatorname{span} v$.

${ }^{I F} D_{u v l} \rightarrow$ Demand of $\mathrm{p}^{\text {th }}$ product in ELMOMTHIFFCTP of $\mathrm{r}^{\text {th }} \mathrm{RT}$ in time $\operatorname{span} v$. 
$C_{v m} \rightarrow$ Capacity of $\mathrm{p}^{\text {th }}$ warehouse in time span v.

$C_{v n} \rightarrow$ Capacity of $\mathrm{n}^{\text {th }}$ distribution centre in time span v.

$C_{v l} \rightarrow$ Capacity of $1^{\text {th }}$ retailer in time span v.

$R W_{\text {vunm }} \rightarrow$ Maximum restrictions on the amount of quantity to be transported from warehouse $m$ to distribution center $\mathrm{n}$ in time time span $\mathrm{v}$.

$R D_{\text {vunl }} \rightarrow$ Maximum restrictions on the amount of quantity to be transported from distribution center $\mathrm{n}$ to particular retailer.

\section{PROBLEM FORMULATION}

The diagrammatic representation of the proposed model for the time span is shown in Fig: 1

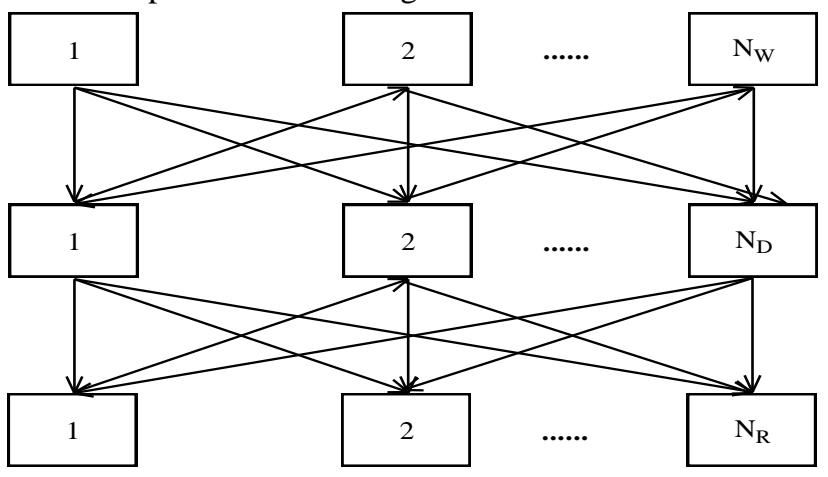

Stage: 1

Fig 1: Two echelon supply chain model

The imprecise objective functions for the first stage are expressed as

$$
\operatorname{Min} F_{1}=\sum_{m=1}^{N_{W}} \sum_{n=1}^{N_{D}} T W_{\text {vumn }}{ }^{I F} d W_{\text {vumn }}, \operatorname{Min} F_{2}=\sum_{m=1}^{N_{W}} \sum_{n=1}^{N_{D}} T W_{\text {vumn }}{ }^{I F} L W_{\text {vumn }}
$$

$\operatorname{Min} F_{3}=\frac{\sum_{m=1}^{N_{W}} \sum_{n=1}^{N_{p r}} I W_{\text {vum }} I C W_{\text {vum }}^{a}}{\sum_{m=1}^{N_{W}} \sum_{u=1}^{N_{p r}} I W_{\text {vum }} I C W_{\text {vum }}^{s}}+\frac{\sum_{m=1}^{N_{W}} \sum_{n=1}^{N_{D}} \sum_{u=1}^{N_{p r}} T W_{\text {vumn }} T C W_{\text {vumn }}^{a}}{\sum_{m=1}^{N_{W}} \sum_{n=1}^{N_{D}} \sum_{u=1}^{N p r} T W_{\text {vumn }} T C W_{\text {vumn }}^{s}}$

Min $F_{4}=\sum_{m=1}^{N_{W}} \sum_{n=1}^{N_{D}} \sum_{u=1}^{N_{p r}} T W_{\text {vumn }} P C_{\text {vum }}+\sum_{m=1}^{N_{W}} \sum_{n=1}^{N_{D}} \sum_{u=1}^{N_{p r}} Q_{\text {vumn }} F D_{\text {vun }} \frac{\left(1-y_{\text {vumn }}\right)}{y_{\text {vumn }}}$

Where ${ }^{I F} d w_{\text {vumn }},{ }^{I F} L W_{\text {vumn }}{ }^{I F} P C_{\text {vum }},{ }^{I F} F D_{\text {vun }}$,

${ }^{I F} Q_{\text {vumn }}$ denote the fuzzy cost coefficient.

The following are the constraints of the stage -I

1. The sum of the units of uth product from a WH to all DC should satisfy the warehouse inventory for a time span $\mathrm{v}$.

$\sum_{n=1}^{N_{D}} T W_{\text {vumn }} \leq I W_{\text {vumn }, m=1,2 \ldots N_{w}, u=1,2 \ldots N_{p r}}$
$\operatorname{MinF}_{5}=\frac{\sum_{m=1}^{N_{W}} \sum_{n=1}^{N_{D}} T W_{\text {vumn }} E C W_{\text {vumn }}^{a}}{\sum_{m=1}^{N_{W}} \sum_{n=1}^{N_{D}} T W_{\text {vumn }} E C W_{\text {vumn }}^{S}}$

2. $\sum_{u=1}^{N_{p r}} I W_{v u m} \leq C_{v m}$ (ie) The sum of inventory at warehouse should be less than or equal to the warehouse capacity in time span $\mathrm{v}$.

3.The sum of the units of product $u$ transferred from all warehouse to a particular distribution center should be greater than or equal to the imprecise forecasted demand of that particular distribution center $\mathrm{n}$ in time span $\mathrm{v}$.

$$
\sum_{u=1}^{N_{W}} T W_{\text {vumn }} \geq{ }^{I F} F D_{\text {vum }}, u=1,2, \ldots N_{p r}, n=1,2 \ldots N_{D}
$$

The total distribution centers imprecise forecasted demand for a time span $v$ should be less than or equal to all warehouse inventory of product $\mathrm{u}$, in that particular time span

$$
\sum_{u=1}^{N_{W}} I W_{\text {vumn }} \geq \sum_{n=1}^{N_{D} I F} F D_{\text {vun }}, u=1,2 \ldots N_{p r}
$$

5. The total number of units transferred from all warehouse to a particular distribution center should be less than or equal to that distribution center capacity

$$
\sum_{m=1}^{N_{W}} \sum_{n=1}^{N_{p r}} T W_{\text {vumn }} \leq C_{v n}, n=1,2 \ldots N_{D}
$$

The units distributed of product $p$ from warehouse $m$ to distribution centre $\mathrm{n}$ in time span $\mathrm{v}$ is less than or equal to maximum restrictions on the amount of quantity to be distributed from warehouse to particular distribution centers.

$$
0 \leq T W_{\text {vumn }} \leq R W_{\text {vumn }}
$$

\section{Stage-II:}

The objective functions for the second stage are expressed as follows:

$$
\operatorname{Min} F_{1}=\sum_{n=1}^{N_{D}} \sum_{l=1}^{N_{r}} T W_{\text {vunl }} d D_{\text {vunl }}, \quad \text { Min } F_{2}=\sum_{n=1}^{N_{D}} \sum_{l=1}^{N_{r}} T W_{\text {vunl }}{ }^{I F} L D_{\text {vunl }}
$$

$\operatorname{Min} F_{3}=\frac{\sum_{n=1}^{N_{D}} \sum_{u=1}^{N_{p r}} I D_{\text {vun }} I C D_{\text {vun }}^{a}}{\sum_{n=1}^{N_{D}} \sum_{u=1}^{N_{p r}} I D_{\text {vun }} I C D_{\text {vun }}^{s}}+\frac{\sum_{n=1}^{N_{D}} \sum_{l=1}^{N_{r}} \sum_{u=1}^{N_{p r}} T D_{\text {vunl }} T C D_{\text {vunl }}^{a}}{\sum_{n=1}^{N_{D}} \sum_{l=1}^{N_{r}} \sum_{p=1}^{N_{p r}} T D_{\text {vunl }} T C D_{\text {vunl }}^{s}}$

$\operatorname{Min} F_{5}=\frac{\sum_{n=1}^{N_{D}} \sum_{k=1}^{N_{r}} T D_{\text {vunl }} E C D_{\text {vunl }}^{a}}{\sum_{J=1}^{N_{D}} \sum_{l=1}^{N_{r}} T D_{\text {vunl }} E C D_{\text {vunl }}^{s}}$

Where $d D_{t p j r}, L D_{t p j r}$ denote the fuzzy cost coefficients.

The constraints of stage-II are as follows:

1. The inventory of product $\mathrm{p}$ at a particular distribution center at the end of stage one is equal to the total number of 
units received from all warehouse by that distribution center minus the actual demand of that particular distribution center in time span.

$$
I D_{v u n}=\sum_{j=1}^{N_{W}} T W_{v u m n}-{ }^{I F} A D_{v u j, l=1,2 \ldots N_{p r}} \ldots
$$

(If this value is negative $I D_{v u n}=0$ ).

2. The sum of units of product $u$ transferred from all distribution centers to a particular retailer should be greater than or equal to the demand of that particular retailer in time span v.

$$
\sum_{n=1}^{N_{D}} T D_{\text {vunl }}{ }^{3} \quad D_{v u l}, u=1,2 \ldots . N_{p r}, l=1,2 \ldots N_{r}
$$

The sum of units of product $P$ transferred from a particular distribution center to all retailers should be less than or equal to the actual demand of that particular distribution center in time span v.

$$
\sum_{n=1}^{N_{D}} T D_{\text {vunl }} \leq{ }^{I F} A D_{\text {vun }}, n=1,2 \ldots . N_{D}, u=1,2 \ldots . N_{p r}
$$

The total number of units transferred from all distribution centers to a particular retailer should be less than or equal to that retailer capacity.

$$
\sum_{n=1}^{N_{D}} \sum_{u=1}^{N_{p r}} T D_{v u n l} \leq C_{v l}, l=1,2 \ldots N_{p r}
$$

The units distributed of product $\mathrm{P}$ from distribution center $\mathrm{n}$ to retailer $\mathrm{l}$ in time span $\mathrm{v}$ is less than or equal to maximum restrictions on the amount of quantity to be transported from distribution center to particular retailer

$$
0 \leq T D_{\text {vunl }} \leq R D_{\text {vunl }}
$$

\section{SOLUTION METHODOLOGY}

Here we have considered environmentally liable multi-objective, multi time span fuzzy fractional capacitated transportation problem in the two echelon supply chain with heterogeneous items and mixed constraints. The uncertainties in the parameters of the model are represented by TIFN. The fuzzy programming approach is used for converting multi objective into single objective.

The membership function for the $K^{\text {th }}$ objective function in the first stage is given below:

$$
\mu_{k}\left(F_{k}(T W)\right)= \begin{cases}1 & \text { if } F_{k}(T W) \leq L B_{k} \\ \frac{U B_{k}-F_{k}(T W)}{U B_{k}-L B_{k}} & \text { if } L B_{k} \leq F_{k}(T W) \leq U B_{k} \\ 0 & \text { if } F_{k}(T W)^{3} U B_{k}\end{cases}
$$

$$
\mu_{k}\left(F_{k}(T W)\right)=\frac{U B_{k}-F_{k}(T W)}{U B_{k}-L B_{k}}, k=1,2 \ldots K
$$

and (5)

$$
0 \leq \mu_{k}\left(F_{k}(T W)\right) \leq 1, k=1,2 \ldots K
$$

The membership function for the $K^{\text {th }}$ objective function in the second stage is given below:

$$
\mu_{k}\left(F_{k}(T D)\right)=\left\{\begin{array}{lc}
1 & \text { if } F_{k}(T D) \leq L B_{k} \\
\frac{U B_{k}-F_{k}(T D)}{U B_{k}-L B_{k}} & \text { if } L B_{k} \leq F_{k}(T D) \leq U B_{k} \\
0 & \text { if } F_{k}(T D)^{3} U B_{k}
\end{array}\right.
$$

Where $U B_{k}$ and $L B_{k}$ are the upper and lower tolerance limit. Now, the equivalent linear model as follows.

$$
\operatorname{Max} D(\mu)=\sum_{k=1}^{K} \mu_{k}\left(F_{k}(T D)\right)
$$

Subject to

$$
\mu_{k}\left(F_{k}(T D)\right)=\frac{U B_{k}-F_{k}(T D)}{U B_{k}-L B_{k}}, k=1,2 \ldots K
$$

and (5)

$$
0 \leq \mu_{k}\left(F_{k}(T D)\right) \leq 1, k=1,2 \ldots K
$$

$\mathrm{D}(\mu)$ is called a fuzzy achievement function or fuzzy decision function. This is a single objective optimization problem which can be solved by using LINGO software.

\section{IMPLEMENTATION AND COMPUTATIONAL ANALYSIS}

One of the leading ghee company located in Tamilnadu is chosen for the application of the proposed methodology. This paper focuses on the transportation of the ghee which is coming in two different packs such as Retailer pack and Bulk pack. We have considered the forecasted demand for these two products in two different time spans. The company has planned to frame a mathematical model to minimize the damage cost, labor cost, quality cost, packing cost and the ratio related to transportation cost, inventory carrying cost, and emission cost of the entire supply chain. This research assumes the same damage cost, labor cost, Inventory carrying cost and packaging cost for all the two products in two different spans.

The following data is collected to substantiate the above developed model.

Let us consider problem of two types products to be transported from one warehouse to three DC and then it distributed to four different retailers in two time spans.

The input data for warehouse distribution centers and retailers are given in tables 1-15.

Where $U B_{k}$ and $L B_{k}$ are the upper and lower tolerance limit.

Now, the equivalent linear model as follows.

$\operatorname{Max} D(\mu)=\sum_{k=1}^{K} \mu_{k}\left(F_{k}(T W)\right)$

Subject to
Published By: 


\section{ENVIRONMENTALLY LIABLE MULTI-OBJECTIVE MULTI TIME SPAN FUZZY FRACTIONAL CAPACITATED TRANSPORTATION PROBLEM IN THE TWO ECHELON SUPPLY CHAIN WITH HETEROGENEOUS ITEMS AND MIXED CONSTRAINTS}

Table: 1 Input data for WH:

\begin{tabular}{|l|c|c|}
\hline $\begin{array}{l}\text { Inventory carrying cost } \\
\text { per unit in Rs }\end{array}$ & $\mathrm{Rs} \frac{1.2}{1.3}$ \\
\hline $\begin{array}{l}\text { warehouse capacity in } \\
\text { units }\end{array}$ & & $7,00,000$ \\
\hline Packing charge & Retailer & $(1,2,3)(0,2,4)$ \\
\cline { 2 - 3 } & Bulk & $(4,6,8)(2,6,10)$ \\
\hline
\end{tabular}

Table: 2 Unit cost of transportation from WH to DC in Rs.

\begin{tabular}{|l|c|c|c|}
\hline $\begin{array}{l}\text { Transportation cost in } \\
\text { Rs from warehouse to }\end{array}$ & \multicolumn{3}{|c|}{ Distribution centers } \\
\cline { 2 - 4 } & D1 & D2 & D3 \\
\cline { 2 - 4 } & $\frac{1.4}{1.2}$ & $\frac{0.5}{0.4}$ & $\frac{1.3}{1.2}$ \\
\hline
\end{tabular}

Table: 3 Unit damage cost from WH to DC in Rs.

\begin{tabular}{|l|c|c|c|}
\hline \multirow{2}{*}{$\begin{array}{l}\text { Damage cost } \\
\text { from } \\
\text { warehouse to }\end{array}$} & \multicolumn{3}{|c|}{ Distribution centers } \\
\cline { 2 - 4 } & $\mathrm{D} 1$ & $\mathrm{D} 2$ & $\mathrm{D} 3$ \\
\cline { 2 - 4 } & $(0.019$, & $(0.019$, & $(0.019$ \\
& $0.039,0.059)$ & 0.039, & 0.039 \\
& $(0,0.039$, & $0.059)$ & $0.059)$ \\
& $0.079)$ & $(0,0.039$, & $(0,0.039$ \\
& & $0.079)$ & $0.079)$ \\
\hline
\end{tabular}

Table: 44 Unit labor cost from WH to DC in Rs.

\begin{tabular}{|l|c|c|c|}
\hline Labor cost from & \multicolumn{3}{|c|}{ Distribution centers } \\
\cline { 2 - 4 } warehouse to & $\mathrm{D} 1$ & $\mathrm{D} 2$ & $\mathrm{D} 3$ \\
\cline { 2 - 4 } & $(0.1,0.2$, & $(0.1,0.2$, & $(0.3$ \\
& $0.3)$ & $0.3)$ & $0.4,0.5)$ \\
& $(0,0.2,0.4)$ & $(0,0.2$, & $(0.2$, \\
& & $0.4)$ & $0.4,0.6)$ \\
\hline
\end{tabular}

Table:5 Unit emission cost from WH to DC in Rs.

\begin{tabular}{|l|c|c|c|}
\hline $\begin{array}{l}\text { Emission cost from } \\
\text { warehouse to }\end{array}$ & \multicolumn{3}{|c|}{ Distribution centers } \\
\cline { 2 - 4 } & $\mathrm{D} 1$ & $\mathrm{D} 2$ & $\mathrm{D} 3$ \\
\cline { 2 - 4 } & $\frac{0.5}{0.4}$ & $\frac{0.06}{0.04}$ & $\frac{0.16}{0.16}$ \\
\hline
\end{tabular}

Table: 6 Distribution centers demand

\begin{tabular}{|c|c|c|c|c|c|c|c|}
\hline \multicolumn{8}{|c|}{ Distribution centers } \\
\hline \multirow[t]{2}{*}{ Span } & \multirow[t]{2}{*}{$\begin{array}{l}\text { Prod } \\
\text { uct }\end{array}$} & \multicolumn{2}{|l|}{ D1 } & \multicolumn{2}{|l|}{ D2 } & \multicolumn{2}{|l|}{ D3 } \\
\hline & & $\begin{array}{l}\text { Forec } \\
\text { asted } \\
\text { demand }\end{array}$ & $\begin{array}{l}\text { Actual } \\
\text { demand }\end{array}$ & $\begin{array}{l}\text { Forecasted } \\
\text { demand }\end{array}$ & $\begin{array}{l}\text { Actual } \\
\text { demand }\end{array}$ & $\begin{array}{l}\text { Foreca } \\
\text { sted } \\
\text { demand }\end{array}$ & $\begin{array}{l}\text { Actual } \\
\text { demand }\end{array}$ \\
\hline $\mathrm{t}_{1}$ & $\mathrm{R}$ & $\begin{array}{l}(5000, \\
6000, \\
7000) \\
(4750, \\
6000, \\
8750)\end{array}$ & $\begin{array}{l}5000, \\
6000, \\
7000) \\
(4643, \\
6000, \\
8643)\end{array}$ & $\begin{array}{l}9600, \\
12,500, \\
12600) \\
(8067, \\
12,500, \\
13067)\end{array}$ & $\begin{array}{l}(9550, \\
12500, \\
12550) \\
(7650, \\
12500 \\
, 12650)\end{array}$ & $\begin{array}{l}(5000, \\
6000, \\
7000) \\
(4643 \\
6000, \\
8643)\end{array}$ & $\begin{array}{l}5000, \\
6000, \\
7000) \\
(4643 \\
6000, \\
8643)\end{array}$ \\
\hline & B & $\begin{array}{l}4500, \\
6000, \\
6500) \\
(3065, \\
6000, \\
7065) \\
\end{array}$ & $\begin{array}{l}4500, \\
6000, \\
6500) \\
(3065, \\
6000, \\
7065) \\
\end{array}$ & $\begin{array}{l}(1000, \\
1250, \\
1300) \\
(950, \\
1250, \\
1450)\end{array}$ & $\begin{array}{c}1000, \\
1250, \\
1300) \\
(950, \\
1250, \\
1450)\end{array}$ & $\begin{array}{l}2935, \\
3000, \\
4935) \\
(1900, \\
3000, \\
5900)\end{array}$ & $\begin{array}{l}2935, \\
3000, \\
4935) \\
(1900, \\
3000, \\
5900)\end{array}$ \\
\hline$t_{2}$ & $\mathrm{R}$ & $\begin{array}{l}(4000, \\
5000, \\
6000) \\
(2800,\end{array}$ & $\begin{array}{l}(4000, \\
5000, \\
6000) \\
(2710,\end{array}$ & $\begin{array}{l}9000, \\
12000, \\
13000) \\
(5800,\end{array}$ & $\begin{array}{l}(9000, \\
12000, \\
13000) \\
(5350,\end{array}$ & $\begin{array}{l}(4000, \\
5000, \\
6000) \\
(2710,\end{array}$ & $\begin{array}{l}(4000, \\
5000, \\
6000) \\
(2710,\end{array}$ \\
\hline
\end{tabular}

\begin{tabular}{|l|l|l|l|l|l|l|l|}
\hline & & 5000, & 5000, & 12000, & 12000, & 5000, & 5000, \\
& & $6800)$ & $6710)$ & $13800)$ & $13350)$ & $6710)$ & $6710)$ \\
\cline { 2 - 7 } & B & $(4000$, & $(4000$, & $(1000$, & $(1000$, & $(2000$, & $(2000$, \\
& 5000, & 5000, & 1033, & 1033, & 3000, & 3000, \\
& $6000)$ & $6000)$ & $1300)$ & $1300)$ & $4000)$ & $4000)$ \\
& $(3300$, & $(3300$, & $(900$, & $(900$, & $(1450$, & $(1450$, \\
& 5000, & 5000, & 1033, & 1033, & 3000, & 3000, \\
& $7300)$ & $7300)$ & $1400)$ & $1400)$ & $5450)$ & $5450)$ \\
\hline
\end{tabular}

Table: 7 Capacitated Restrictions on the route from WH to DC.

\begin{tabular}{|c|c|c|c|c|}
\hline Time span & \multirow{2}{*}{ Product } & \multicolumn{3}{|c|}{} \\
\cline { 3 - 5 } & & \multicolumn{3}{|c|}{ Distribution centers. } \\
\cline { 3 - 5 } & & D1 & D2 & D3 \\
\hline \multirow{3}{*}{ 1 } & $\mathrm{R}$ & 3200 & 7000 & 3250 \\
\cline { 2 - 5 } & $\mathrm{B}$ & 3000 & 800 & 2000 \\
\cline { 2 - 5 } & $\mathrm{R}$ & 2500 & 6000 & 3000 \\
\hline $\mathrm{t} 2$ & $\mathrm{~B}$ & 2800 & 700 & 1800 \\
\hline
\end{tabular}

Table: 8 Inputs for DC:-

\begin{tabular}{|l|c|c|c|}
\hline & \multicolumn{3}{|c|}{ Distribution center } \\
\hline & $\mathrm{D} 1$ & $\mathrm{D} 2$ & $\mathrm{D} 3$ \\
\hline $\begin{array}{l}\text { Inventory } \\
\text { carrying cost } \\
\text { per unit in Rs }\end{array}$ & $\frac{1.6}{1.4}$ & $\frac{1.4}{1.2}$ & $\frac{1.4}{1.3}$ \\
\hline $\begin{array}{l}\text { capacity in } \\
\text { units }\end{array}$ & $1,61,000$ & $2,80,000$ & 10,000 \\
\hline
\end{tabular}

Table:9 Unit transportation cost from DC to RT in Rs

\begin{tabular}{|c|c|c|c|c|}
\hline \multicolumn{5}{|c|}{ Retailer } \\
\hline $\begin{array}{c}\text { Distribution } \\
\text { centers }\end{array}$ & $\mathrm{R} 1$ & $\mathrm{R} 2$ & $\mathrm{R} 3$ & $\mathrm{R} 4$ \\
\hline D1 & $\frac{0.02}{0.01}$ & $\frac{0.04}{0.03}$ & $\frac{0.4}{0.3}$ & $\frac{0.2}{0.1}$ \\
\hline D2 & $\frac{0.3}{0.2}$ & $\frac{0.3}{0.2}$ & $\frac{0.004}{0.003}$ & $\frac{0.2}{0.1}$ \\
\hline D3 & $\frac{0.2}{0.1}$ & $\frac{0.18}{0.15}$ & $\frac{0.3}{0.2}$ & $\frac{0.01}{0.01}$ \\
\hline
\end{tabular}

Table: 10 Unit Damage cost from DC to RT in Rs.

\begin{tabular}{|c|c|c|c|c|}
\hline \multicolumn{5}{|c|}{ Retailers } \\
\hline $\begin{array}{l}\text { Distribut } \\
\text { ion } \\
\text { centers }\end{array}$ & $\mathrm{R} 1$ & $\mathrm{R} 2$ & $\mathrm{R} 3$ & $\mathrm{R} 4$ \\
\hline \multicolumn{1}{|c|}{$\mathrm{D} 1$} & $(0.019,0.039$, & $(0.019,0.039$, & $(0.019,0.03$ & $(0.019,0.039$, \\
& $0.059)$ & $0.059)$ & $9,0.059)$ & $0.059)$ \\
& $(0,0.039$, & $(0,0.039$, & $(0,0.039$, & $(0,0.039$, \\
& $0.079)$ & $0.079)$ & $0.079)$ & $0.079)$ \\
\hline D2 & $(0.019,0.039$, & $(0.019,0.039$, & $(0.019,0.03$ & $(0.019,0.039$, \\
& $0.059)$ & $0.059)$ & $9,0.059)$ & $0.059)$ \\
& $(0,0.039$, & $(0,0.039$, & $(0,0.039$, & $(0,0.039$, \\
& $0.079)$ & $0.079)$ & $0.079)$ & $0.079)$ \\
\hline D3 & $(0.019,0.039$, & $(0.019,0.039$, & $(0.019,0.03$ & $(0.019,0.039$, \\
& $0.059)$ & $0.059)$ & $9,0.059)$ & $0.059)$ \\
& $(0,0.039$, & $(0,0.039$, & $(0,0.039$, & $(0,0.039$, \\
& $0.079)$ & $0.079)$ & $0.079)$ & $0.079)$ \\
\hline
\end{tabular}


Table:11Unit labor cost from DC to RT in Rs.

\begin{tabular}{|c|c|c|c|c|c|c|}
\hline \multicolumn{7}{|c|}{ Retailers } \\
\hline $\begin{array}{l}\text { Distributio } \\
\mathrm{n} \text { centers }\end{array}$ & \multicolumn{2}{|c|}{ R1 } & \multicolumn{2}{|c|}{ R2 } & R3 & R4 \\
\hline D1 & \multicolumn{2}{|c|}{$\begin{array}{l}(0.1, \quad 0.2, \\
0.3) \\
(0,0.2,0.4)\end{array}$} & \multicolumn{2}{|c|}{$\begin{array}{l}(0.1,0.2,0.3) \\
(0,0.2,0.4)\end{array}$} & $\begin{array}{l}(0.1,0.2,0.3) \\
(0,0.2,0.4)\end{array}$ & $\begin{array}{ll}(0.1, & 0.2, \\
0.3) & \\
(0, & 0.2, \\
0.4) & \end{array}$ \\
\hline D2 & \multicolumn{2}{|c|}{$\begin{array}{l}(0.1, \quad 0.2, \\
0.3) \\
(0,0.2,0.4)\end{array}$} & \multicolumn{2}{|c|}{$\begin{array}{l}(0.1,0.2,0.3) \\
(0,0.2,0.4)\end{array}$} & $\begin{array}{l}(0.1,0.2,0.3) \\
(0,0.2,0.4)\end{array}$ & $\begin{array}{ll}(0.1, & 0.2, \\
0.3) & \\
(0, & 0.2, \\
0.4) & \end{array}$ \\
\hline D3 & \multicolumn{2}{|c|}{$\begin{array}{l}(0.3,0.4, \\
0.5) \\
(0.2,0.4 \\
0.6)\end{array}$} & \multicolumn{2}{|c|}{$\begin{array}{l}(0.3,0.4,0.5) \\
(0.2,0.4,0.6)\end{array}$} & $\begin{array}{l}(0.3,0.4,0.5) \\
(0.2,0.4,0.6)\end{array}$ & $\begin{array}{l}(0.3,0.4, \\
0.5) \\
(0.2,0.4, \\
0.6)\end{array}$ \\
\hline \multicolumn{7}{|c|}{ Table:12 Unit emission cost from DC to RT in Rs. } \\
\hline \multicolumn{7}{|c|}{ Retailer } \\
\hline \multicolumn{2}{|c|}{$\begin{array}{c}\text { Distribution } \\
\text { centers }\end{array}$} & \multicolumn{2}{|c|}{ R1 } & $\mathrm{R} 2$ & R3 & $\mathrm{R} 4$ \\
\hline \multirow{2}{*}{\multicolumn{2}{|c|}{ D1 }} & \multicolumn{2}{|c|}{0.03} & 0.04 & 0.5 & 0.16 \\
\hline & & \multicolumn{2}{|c|}{0.02} & 0.03 & 0.4 & 0.12 \\
\hline \multirow{2}{*}{\multicolumn{2}{|c|}{ D2 }} & \multicolumn{2}{|c|}{0.4} & 0.4 & 0.005 & 0.3 \\
\hline & & \multicolumn{2}{|c|}{0.4} & $\overline{0.3}$ & 0.004 & 0.25 \\
\hline \multirow[t]{2}{*}{ D3 } & & \multicolumn{2}{|c|}{0.16} & 0.15 & 0.25 & 0.008 \\
\hline & & \multicolumn{2}{|c|}{$\overline{0.15}$} & $\overline{0.14}$ & 0.2 & 0.008 \\
\hline
\end{tabular}

Table:13 Retailer demand.

\begin{tabular}{|c|c|c|c|c|c|}
\hline \multicolumn{6}{|c|}{ Distribution centers. } \\
\hline $\begin{array}{l}\text { Time } \\
\text { span }\end{array}$ & $\begin{array}{l}\text { Produc } \\
\mathrm{t}\end{array}$ & $\mathrm{R} 1$ & $\mathrm{R} 2$ & R3 & $\mathrm{R} 4$ \\
\hline \multirow[t]{2}{*}{$\mathrm{t} 1$} & $\mathrm{R}$ & $\begin{array}{c}(1440, \\
1600, \\
1760) \\
(1280, \\
1600, \\
1920)\end{array}$ & $\begin{array}{l}(1800, \\
2000, \\
2200) \\
(1600, \\
2000, \\
2400)\end{array}$ & $\begin{array}{l}(1800, \\
2000, \\
2200) \\
(1600, \\
2000, \\
2400) \\
\end{array}$ & $\begin{array}{l}(360, \\
400, \\
440) \\
(320, \\
400, \\
480)\end{array}$ \\
\hline & B & $\begin{array}{c}(1260, \\
1400, \\
1540) \\
(1120, \\
1400, \\
1680) \\
\end{array}$ & $\begin{array}{c}(1500, \\
1800, \\
2100) \\
(1200, \\
1800, \\
2400) \\
\end{array}$ & $\begin{array}{l}(1500, \\
1800, \\
2100) \\
(1200, \\
1800, \\
2400) \\
\end{array}$ & $\begin{array}{c}(500, \\
600, \\
700) \\
(400, \\
600, \\
800) \\
\end{array}$ \\
\hline \multirow[t]{2}{*}{$\mathrm{t} 2$} & $\mathrm{R}$ & $\begin{array}{c}(1440, \\
1600, \\
1760) \\
(1280, \\
1600, \\
1920) \\
\end{array}$ & $\begin{array}{c}(1440, \\
1600, \\
1760) \\
(1280, \\
1600, \\
1920) \\
\end{array}$ & $\begin{array}{l}(1000, \\
1200, \\
1400) \\
(800, \\
1200, \\
1600) \\
\end{array}$ & $\begin{array}{c}(360, \\
400, \\
440) \\
(320, \\
400,480 \\
)\end{array}$ \\
\hline & B & $\begin{array}{l}(1260, \\
1400, \\
1540) \\
(1120, \\
1400, \\
1680)\end{array}$ & $\begin{array}{c}(1440, \\
1600, \\
1760) \\
(1280, \\
1600, \\
1920)\end{array}$ & $\begin{array}{l}(1000, \\
1200, \\
1400) \\
(800, \\
1200, \\
1600)\end{array}$ & $\begin{array}{c}(500, \\
600, \\
700) \\
(400, \\
600, \\
800)\end{array}$ \\
\hline
\end{tabular}

Table:14 Capacitated Restrictions on the route from DC to RT

\begin{tabular}{|c|c|c|c|c|c|c|}
\hline \multicolumn{7}{|c|}{ Retailer } \\
\hline \multirow{2}{*}{} & Span & $\begin{array}{c}\text { Prod } \\
\text { uct }\end{array}$ & R1 & R2 & R3 & R4 \\
\hline \multirow{3}{*}{ D1 } & \multirow{2}{*}{$\mathrm{t}_{1}$} & $\mathrm{R}$ & 900 & 1200 & 1200 & 250 \\
\cline { 3 - 7 } & \multirow{2}{*}{$\mathrm{t}_{2}$} & $\mathrm{~B}$ & 750 & 950 & 1000 & 350 \\
\cline { 3 - 7 } & & $\mathrm{R}$ & 800 & 850 & 700 & 200 \\
\cline { 3 - 7 } & & $\mathrm{B}$ & 750 & 800 & 600 & 350 \\
\hline
\end{tabular}

\begin{tabular}{|c|c|c|c|c|c|c|}
\hline \multirow{2}{*}{ D2 } & $\mathrm{t}_{1}$ & $\mathrm{R}$ & $\begin{array}{c}250 \\
0\end{array}$ & 3000 & 750 & 1000 \\
\cline { 3 - 7 } & & $\mathrm{B}$ & 250 & 200 & 200 & 150 \\
\cline { 3 - 7 } & \multirow{2}{*}{$\mathrm{t}_{2}$} & $\mathrm{R}$ & $\begin{array}{c}150 \\
0\end{array}$ & 1600 & 1500 & 1000 \\
& & $\mathrm{~B}$ & 250 & 200 & 150 & 160 \\
\hline \multirow{3}{*}{ D3 } & \multirow{2}{*}{$\mathrm{t}_{1}$} & $\mathrm{R}$ & $\begin{array}{c}100 \\
0\end{array}$ & 1200 & 800 & 500 \\
\cline { 3 - 7 } & & $\mathrm{B}$ & 500 & 600 & 550 & 100 \\
\cline { 3 - 7 } & \multirow{2}{*}{$\mathrm{t}_{2}$} & $\mathrm{R}$ & 900 & 800 & 750 & 250 \\
\cline { 3 - 7 } & & $\mathrm{B}$ & 500 & 350 & 500 & 350 \\
\hline
\end{tabular}

Table:15 Inputs for RT

\begin{tabular}{|c|c|c|c|c|}
\multirow{2}{*}{ Retailer } & \multicolumn{4}{|c|}{ Retailer } \\
\cline { 2 - 5 } Capacity & $\mathrm{R} 1$ & $\mathrm{R} 2$ & $\mathrm{R} 3$ & $\mathrm{R} 4$ \\
\hline & $1,20,00$ & 75,00 & 60,00 & 50,00 \\
& 0 & 0 & 0 & 0 \\
\hline
\end{tabular}

\section{RESULTS}

After solving the model for two stages using Lingo software, the optimal solution for the case study are obtained these results are tabulated in table: 16-22.

Table:16 Optimal warehouse stock

\begin{tabular}{|c|c|c|}
\hline Span & Product & Number of units \\
\hline \multirow{2}{*}{$t_{1}$} & R & IW 111=13177.85 \\
\cline { 2 - 3 } & B & IW $121=5283.8$ \\
\hline \multirow{2}{*}{$t_{2}$} & R & IW 211=10539.75 \\
\cline { 2 - 3 } & B & IW 221 =5012 \\
\hline
\end{tabular}

Table:17 Optimal number of units transferred from WH to DC

\begin{tabular}{|c|c|c|c|c|}
\hline Span & Product & \multicolumn{3}{|c|}{ Numbers of units } \\
\hline & & D1 & D2 & D3 \\
\hline \multirow{2}{*}{$\mathrm{t}_{1}$} & $\mathrm{R}$ & 3094 & 7000 & 3081 \\
\cline { 2 - 5 } & $\mathrm{B}$ & 2821 & 728 & 1730 \\
\hline \multirow{2}{*}{$\mathrm{t}_{2}$} & $\mathrm{R}$ & 2475 & 5600 & 2464 \\
\cline { 2 - 5 } & $\mathrm{B}$ & 2800 & 655 & 1557 \\
\hline
\end{tabular}

Table:18 Optimal inventory in units at DC

\begin{tabular}{|c|c|c|c|c|}
\hline Span & Product & \multicolumn{3}{|c|}{ distribution centers } \\
\hline & & D1 & D2 & D3 \\
\hline \multirow[t]{2}{*}{$t_{1}$} & $\mathrm{R}$ & ID111 = 13.7 & ID112 $=70$ & $\begin{array}{l}\text { ID113 } \\
=.7\end{array}$ \\
\hline & B & $\begin{aligned} & \text { ID121 } \\
= & .4^{1}\end{aligned}$ & ID122 $=.5$ & $\begin{array}{l}\text { ID123 } \\
=.7\end{array}$ \\
\hline \multirow[t]{2}{*}{$t_{2}$} & $\mathrm{R}$ & ID211=11.25 & ID212 $=56.25$ & $\begin{array}{l}\text { ID213 } \\
=.25\end{array}$ \\
\hline & B & ID221=262.5 & ID222 $=0.1$ & $\begin{array}{l}\text { ID223 } \\
=0.75\end{array}$ \\
\hline
\end{tabular}




\section{ENVIRONMENTALLY LIABLE MULTI-OBJECTIVE MULTI TIME SPAN FUZZY FRACTIONAL CAPACITATED TRANSPORTATION PROBLEM IN THE TWO ECHELON SUPPLY CHAIN WITH HETEROGENEOUS ITEMS AND MIXED CONSTRAINTS}

Table:19 Optimal number of units transferred from DC to RT

\begin{tabular}{|c|c|c|c|c|c|c|}
\hline \multicolumn{7}{|c|}{ Retailers } \\
\hline $\begin{array}{l}\text { Distribut } \\
\text { ion } \\
\text { centers }\end{array}$ & $\begin{array}{l}\text { Time } \\
\text { span }\end{array}$ & $\begin{array}{l}\text { Prod } \\
\text { uct }\end{array}$ & R1 & R2 & R3 & R4 \\
\hline \multirow{4}{*}{ D1 } & \multirow[t]{2}{*}{$t_{1}$} & $\mathrm{R}$ & $\begin{array}{c}\text { TD1111 } \\
0\end{array}$ & $\begin{array}{c}\text { TD1112 } \\
1200\end{array}$ & $\begin{array}{c}\text { TD1113 } \\
0\end{array}$ & $\begin{array}{c}\text { TD1114 } \\
0\end{array}$ \\
\hline & & B & $\begin{array}{c}\text { TD1211 } \\
200\end{array}$ & $\begin{array}{c}\text { TD1212 } \\
900\end{array}$ & $\begin{array}{c}\text { TD1213 } \\
700\end{array}$ & $\begin{array}{c}\text { TD1214 } \\
150\end{array}$ \\
\hline & \multirow[t]{2}{*}{$\mathrm{t}_{2}$} & $\mathrm{R}$ & $\begin{array}{c}\text { TD2111 } \\
0\end{array}$ & $\begin{array}{c}\text { TD2112 } \\
200\end{array}$ & $\begin{array}{c}\text { TD2113 } \\
0\end{array}$ & $\begin{array}{c}\text { TD2114 } \\
0\end{array}$ \\
\hline & & B & $\begin{array}{c}\text { TD2211 } \\
700\end{array}$ & $\begin{array}{c}\text { TD2212 } \\
600\end{array}$ & $\begin{array}{c}\text { TD2213 } \\
0\end{array}$ & $\begin{array}{c}\text { TD2214 } \\
300\end{array}$ \\
\hline \multirow{4}{*}{ D2 } & \multirow[t]{2}{*}{$t_{1}$} & $\mathrm{R}$ & $\begin{array}{c}\text { TD1121 } \\
2052\end{array}$ & $\begin{array}{c}\text { TD1122 } \\
0\end{array}$ & $\begin{array}{c}\text { TD1123 } \\
750\end{array}$ & $\begin{array}{c}\text { TD1124 } \\
0\end{array}$ \\
\hline & & B & $\begin{array}{c}\text { TD1221 } \\
0\end{array}$ & $\begin{array}{c}\text { TD1222 } \\
0\end{array}$ & $\begin{array}{r}\text { TD1223 } \\
200\end{array}$ & $\begin{array}{c}\text { TD1224 } \\
150\end{array}$ \\
\hline & \multirow[t]{2}{*}{$\mathrm{t}_{2}$} & $\mathrm{R}$ & $\begin{array}{c}\text { TD2121 } \\
1000\end{array}$ & $\begin{array}{c}\text { TD2122 } \\
0\end{array}$ & $\begin{array}{c}\text { TD2123 } \\
1000\end{array}$ & $\begin{array}{c}\text { TD2124 } \\
900\end{array}$ \\
\hline & & B & $\begin{array}{c}\text { TD2221 } \\
0\end{array}$ & $\begin{array}{c}\text { TD2222 } \\
200\end{array}$ & $\begin{array}{c}\text { TD2223 } \\
100\end{array}$ & $\begin{array}{c}\text { TD2224 } \\
0\end{array}$ \\
\hline \multirow{4}{*}{ D3 } & \multirow[t]{2}{*}{$t_{1}$} & $\mathrm{R}$ & $\begin{array}{c}\text { TD1131 } \\
0\end{array}$ & $\begin{array}{c}\text { TD1132 } \\
800\end{array}$ & $\begin{array}{c}\text { TD1133 } \\
250\end{array}$ & $\begin{array}{c}\text { TD1134 } \\
400\end{array}$ \\
\hline & & B & $\begin{array}{c}\text { TD1231 } \\
500\end{array}$ & $\begin{array}{c}\text { TD1232 } \\
0\end{array}$ & $\begin{array}{c}\text { TD1233 } \\
0\end{array}$ & $\begin{array}{c}\text { TD1234 } \\
0\end{array}$ \\
\hline & \multirow[t]{2}{*}{$\mathrm{t}_{2}$} & $\mathrm{R}$ & $\begin{array}{c}\text { TD2131 } \\
0\end{array}$ & $\begin{array}{c}\text { TD2132 } \\
800\end{array}$ & $\begin{array}{c}\text { TD2133 } \\
0\end{array}$ & $\begin{array}{c}\text { TD2134 } \\
0\end{array}$ \\
\hline & & B & $\begin{array}{c}\text { TD2231 } \\
0 \\
\end{array}$ & $\begin{array}{c}\text { TD2232 } \\
0 \\
\end{array}$ & $\begin{array}{c}\text { TD2233 } \\
500\end{array}$ & $\begin{array}{c}\text { TD2234 } \\
0 \\
\end{array}$ \\
\hline
\end{tabular}

Table:20 Optimal Cost

\begin{tabular}{|c|c|c|c|}
\hline & Stage: 1 & Stage: 2 & $\begin{array}{c}\text { Optimal } \\
\text { total cost }\end{array}$ \\
\hline Damage & $\begin{array}{c}\mathrm{F} 1= \\
1057.735\end{array}$ & $\begin{array}{c}\mathrm{F} 1= \\
484.4880\end{array}$ & 1542.223 \\
\hline Labor & $\begin{array}{c}\mathrm{F} 2= \\
9163.945\end{array}$ & $\begin{array}{c}\mathrm{F} 2= \\
4015.200\end{array}$ & 13179.145 \\
\hline $\mathrm{IC}+\mathrm{TC}$ & $\mathrm{F} 3=$ & $\mathrm{F} 3=$ & 4.456516 \\
& 2.101379 & 2.355137 & \\
\hline $\mathrm{Co}_{2}$ & $\mathrm{~F} 5=$ & $\mathrm{F} 5=$ & 2.331083 \\
& 1.233504 & 1.097579 & \\
\hline $\mathrm{PC}+\mathrm{QC}$ & $\mathrm{F} 4=$ & - & - \\
& 55070.30 & & \\
\hline
\end{tabular}

\section{CONCLUSION}

In this paper environmentally liable multi-objective multi time span fuzzy fractional capacitated transportation problem in the two echelon supply chain with heterogeneous items and mixed constraints model is proposed. The main objective of this proposed model is to minimize the damage cost, labor cost, quality cost, packing cost and the ratio related to transportation cost, inventory carrying cost and emission cost of the entire supply chain. In this model the emission cost, cost related to transportation and inventory are expressed as fractional objectives which is the most effective way to describe the system. So it would be helpful to the decision makers to understand the supply chain system in a better way. An industry is taken for a case study and proposed procedure is applied to determine the feasibility of this model in a supply chain. In particular, this methodology can be easily extended to real life decision making problems in supply chains.

\section{REFERENCES}

1. Ana Maria. S, Rakesh. N, 1999, A review of integrated analysis of production and distribution systems, IIE Transactions 31 1061-1074.

2. Atanassov.K.T., Intuitionistic fuzzy sets, Fuzzy Sets and Systems, 1986, 87-96.

3. Bask, A.H., 2001, Relationships among TPL providers and members of supply chains: a strategic perspective. Journal of Business \& Industrial Marketing, 2001, 16 (6), 470-486.

4. Bhargava, A.K., singh., S.R., Bansal, D. Multi-objective fuzzy chance constrained fuzzy goal programming for capacitated transportation problem. Int. J. Compute. Appl. 107 (3), 18-23 (2014).

5. B.J. La Londe, JM Masters-Emerging logistics strategies. Int. Journal of physical distribution \& logistic management / volume 24, Issue 7.

6. B.M. Beamon, 2004, Supply chain design and analytical models: models and methods, Int. Journal of production Economics 55 (1998) 281-294.

7. chen, B. Bilgen, I. Ozkarahan, strategic tactical and operational production-distribution models: a review Int. Journal of Technology management 28 151-171.

8. Childhouse P, Towill DR, 2003, Simplified material flow holds the key to supply chain integration, OMEGA, 31 (1): 17-27.

9. Deng-Feng-Li, A note on "Using intuitionistic fuzzy sets for fault tree analysis on printed circuit board assembly", Micro Electronics Reliability, 2008, 48, 1741.

10. Disney S.M. and Towill D.R., 2003, Vendor-managed inventory and bullwhip reduction in a two-level supply chain, Int. Journal of operations and production management, Vol.23 No.6.PP.625-651.

11. D.M. Lambert JR stock, LM. Ellram -1998 fundamentals of logistics management.

12. D. Petrovic, 2001 Simulation of supply chain behavior and performance in an uncertain environment, Int. Journal of production Economics 71, 429-438.

13. D. Petrovic, R. Roy, R. Petrovic, 1998, Modelling and simulation of a supply chain in an uncertain environment, European Journal of operational Research 109, 299-309.

14. Guidelines for measuring and mangling $\mathrm{Co} 2$ emission from freight transport operations Issue: 1 March 2011

15. Gupta. N., Ali. I., Bari. A.: A compromise solution for multi-objective chance constraint capacitated transportation problem, prob stat forum 6, 60-67 (2013).

16. Gupta. N., Bari, A,. Fuzzy multi-objective capacitated transportation problem with mixed constraints. J. stat. Appl. Probab. 3 (2), 1-9 (2014).

17. Hitchcok, F.L., The distribution of a product from several sources to numerous localities J. Math. Phys. 20, 224-230 (1941).

18. Koopmans, T.C., Reiter, S. A model of transportation In: Koopmans, T.J.C. (ed.) Activity analysis of production and Allocation-proceedings of a conference, PP. 222-259. Wiley, New York (1951).

19. L., Lee, W., 2004, Multi-objective optimization of multi echelon supply chain networks with uncertain product demands and prices, computers and chemical Engineering 28, PP. 1131-1144.

20. Lohgaonkar, M.H., bajaj V.H.: Fuzzy approach to solve multi-objective capacitated transportation problem. Int. J. Bioinform. Res. 2, 10-14 (2010).

21. Mahapatra.G.S., and Roy.T.K., Reliability Evaluation using Triangular Intuitionistic Fuzzy numbers Arithmetic operations, World Academy of science, Engineering and Technology 2009, 50, 574-581.

22. Potter, A. and Lalwani, C., 2005 supply chain, dynamics and transport management: A review, Proceedings of the 10th logistic Research Network conference, Plymouth, 7th-9th September.

23. Pramanik, S., Banerjee, D. : Multi-objective chance constrained capacitated transportation problem based on fuzzy goal programming Int. J. computer, Appl. 44 (20), $42-46$ (2012).

24. Pyke D.F., Cohen M.A., 1993, performance characteristics of stochastic integrated production distribution systems, European Journal of operational Research 68 (1), PP. 23-48. 
25. Sadia, S., Gupta, N., Ali, Q.M. : multi-objective capacitated fractional transportation problem with mixed constraints. Math Sci.Lett.5(3), 235-242 (2016)

26. S.K. Bhanati: Ranking method of Intritienrtion fuzzy numbers Global journal of pare and Applied mathematics. Vol-13 Number 9 (2017). PP. 4595-4608

27. Stank T and Goldsby TJ, 2000, A framework for transportation decision making in an integrated supply chain.Supply chain management. An Int. J. Vol 5: No.2.

28. Srikant Gupta, IrfanAli, Aquil Ahmed: Multi-objective capacitated transportation problem with mixed constraint: a case study of certain and uncertain environment, operational Research society of India 2018,

29. S.S. Erengiic, N.C . Simpson, A.J. Vakharia, 1999 Integrated production/ distribution planning in supply chains: and invited review, European Journal of Operational Research 115, 219-236.

30. Subramanian. P, Ramkumar. N, T.T. Narendran, 2010 , Mathematical model for multi-echelon, multi-product, single time-period closed loop supply chain, Int-Journal of Business performance and supply chain modeling, Vol 2, No.3/4 PP 216-236.

31. Tuzkaya U., ÖnÜt S., 2009, A holonic approach based integration methodology for transportation and warehousing functions of the supply network, computers and Industrial Engineering 56, PP. 708-723.

32. Wagner, H.M. : On a class of capacitated transportation problems. Manag. Sci. 5(3), 304-318 (1959).

33. Williams J.F., 1981, Heuristic techniques for simultaneous scheduling of production and distribution in multi-echelon structures: Theory and empirical comparisons, Management science 27 (3), PP. 336-352.

34. ZadehL A 1978 Fuzzy Set Syst.1 3-28 